\title{
The War as a Philosophical Problem
}

\author{
Assist. Prof. Dr. Aysel Demir
}

\begin{abstract}
War is a philosophical problem that can be judged as a human action. Especially Just War Theory holds that morals do apply to war. Aristotle, Cicero, Augustine, Aquinas are among the philosophers who have espoused some form of a just war philosophy. In this sense, I will analyze the tactics, the strategies and the philosophical basis of war ethically in this study. I explore the aim and structure of the war and I will ask when should a state go to war? In what ways and to what extent should a nation influence other nations short of declaring war? What legal rules and ethical principles should govern how we conduct the war?

The history of war is fairly old however early war raids were not well organized because of not having any formal training. War involves the use of force and killing which aim to capture the other. War can be seen both as a universal and ancestral aspect of human nature and as a result of specific socio-cultural or ecological circumstances. War has been morphing for ages and particularly the nature of war changed. The origins of conventional war were always in governments. However, these days individuals can wage war. Today, the fast pace of technological change, an increasing level of knowledge in every imaginable party and group, easy access across borders made more porous for the purpose of international trade and investment, and a rapidly increasing global population combine to shift not merely the tactics and strategies, but the very nature of war itself. The weapons of choice have become backpack bombs, computer and biological viruses, and chemicals. Terrorism is the next highest stage of war. Unarmed actors thousands of miles away can participate in a conflict even by sitting at their computer, a different form of unconventional warfare is emerging in the 21 st century.

War is justifiable in the protection of core rights and it is only justified if waged in a state or nation's self-defence, or waged in order to end gross violations of human rights.
\end{abstract}

Keywords - War, Politics, Ethics, Strategy, Philosophical Problem, Just War Theory

\section{INTRODUCTION}

$\mathrm{W}$ AR is good for absolutely nothing. Although everyone is yearning for peace and everyone talks about it, people usually leave an open door for war. Law, justice, freedom, equality and human rights are important qualifications to provide peace, however the absence of one or more of them creates a problem for social order and can lead to national or international war. War is a conflict which is involves the organized use of weapons and physical force by states.

In the 21 st Century, the format of war has been changed in different ways by the effect of technological revolution, but this change has been presented as bringing justice and democracy, appearing to be designed to apply the rule of law

Kirikkale University Philosophy Department ayselmus1 @ hotmail.com 00905325787031). for human beings.

Throughout history people have found themselves in the war as active or passive participants. Sometimes the violence has been forced on them by others or they are forcing violence on others, acting under pressure through the use of force. Wars are usually based on religious, national, political and economical problems and advantages among states or social groups. People have been waging war against different aims and this has been a subject of both philosophical and historical arguments concerned with war. The war philosophy is examine the meaning of the war for human being, the origin of war and its ethics. The morality of war has been the subject of debate for thousands of years. War has existed since human beings began to be socialized. In this sense, Heraclitus, the ancient Greek philosopher, said "War is the father of all things." (Kranz, 1984, p.58) War is the result of a struggle for existence in the universe.

The main motive of war is hostile intentions and behavior. These hostile intention turns to the hegemony. War is a conflict of wills and any kind of violence can be used to impose these wills. Although war is a state of armed conflict between societies, war can be defined clearly as the conflict of wills or a power test. Opposite society or state is exposure to violence through the coercion and pressure used in war. Violence is a formalizing tool for warring factions.

War based on mutual violence and moves via the use of force and power with armed or unarmed attack. States are on a political power trip to protect their interests or to take advantage of war. War is not merely a political act, but also a real political instrument. The government, military and public have been in war actively as affecting and affected. Therefore war and its results attribute to every segment of society. The subject of war and peace is the state and it has a sovereignty right to ensure the sustainability of states. To talk about war of a state, firstly, at least one of the states must explicitly declare a war which means this situation emerges a mutual war law.

Power use tools have changed in war through the ages and war strategies have also taken advantage of this change. Strategy determines the nature of war. In this sense, SUN TZU, who lived in the 6th Century BC gave military tactics about war and also wrote a book - The Art of War which contains many war strategies. These strategies refer to which methods can be used to beat the enemy, coercion and pressure that can be used, how the enemy is to be captured and how captured people will be protected in war. According to this, the strategy, laid down for the implementation of political goals should show the political dimensions and should apply in 
the context of results-methods-war tools to win war. (Baker and Stephens, 2009, p.16). The results refer to victory, methods refer to military diplomacy and economic sanction, war tools refer to weapon and monetary resource. When they are applied systematically, then war strategy is successful. In this context, states should take into consideration all political, economic, and all the other factors strategically before going to war. (Baker and Stephens, 2009, p.18) A strategical war always changes towards the power balance. This means strategy changes the balance and the same time it helps to realize a just implementation and its protection. War that is waged as justified and legitimate is thought to be ethical.

Within just war theory, the moral issues surrounding war are traditionally divided into two main categories. Jus ad bellum concerns the justification to resort to war in the first place, a question typically addressed to heads of state. Jus in bello is justice in war, referring to correct conduct in battle once the decision to go to war has been made, usually the concern of combatants, generals and soldiers. A third category has more recently entered discussion: Jus post bellum or justice after war, concerned with making a just peace and the responsibility and accountability of parties after war has ended. To satisfy the principles of jus ad bellum, a war must be in the service of a just cause, must have been commissioned by a legitimate authority and must be waged for a right intention. War has to have been the last resort for keeping peace, should have a high probability of success and cannot cause harm disproportionate to the amount of good it is expected to achieve. The understanding of what each of those categories entails can be debated, but if even one of these conditions is not fulfilled quite a high standard - any war embarked upon is unjust.

When we look at the history of philosophy, we can see that philosophers have had some discussions about war and the origin of war. In this context, Heraclitus' words are very important for us. According to him "War is the father of all things." War is a mandatory sovereign force for universe and all things come to pass in accordance with Logos. Heraclitus calls the oppositional processes "strife", and hypothesizes that the apparently stable state or "justice," is a harmony of it. We must know that war is common to all and strife is justice, and that all things come into being through strife necessarily. All things come into being by conflict of opposites. Heraclitus declares that war is a reason for "becoming". Although Becoming is a condition in life, some philosophers such as Hobbes, Rousseau and Kant are not in agreement with him. According to them, war is not a result of "becoming", on the contrary it is a result of circumstances in life. Hobbes especially believes in that people are inherently "bad", and Rousseau believes that being good or bad depends on the circumstances of life (Kışlalı, 2010, p. 34).

Plato wrote two important books about state, politics and war, the Republic and Laws. Plato's writings were obviously influenced by the Peloponnesian war that had a long lasting impact on Athens, due to the massive loss of life. In the Republic, Plato regards the role of military ethics as crucial in the construction of the ideal city and he sees limitation of brutality and more generally a philosophical approach to the use of force as crucial elements of the city's approach to warfare. In Laws, he does insist that war must serve peace, and thus war is no goal in itself but merely a means to peace and complete moral virtue. He did not write any single dialogue with war explicitly, but war and human conflict are central topics in the Republic. The question of the origin of war is central to the discussion of different cities in book II. Indeed, in the Republic, preparation for war commands a crucial place in the set-up of the ideal city, with the soldiering class singled out for special attention and with an emphasis being put on its education and moral character. According to the argument, war is an unavoidable consequence of the desire to have and own ever more - a desire that seems unavoidable once a taste for luxuries and the finer sides of life has started manifesting itself (The Republic, 1995, p. 63). Socrates states boldly, "the origin of war - in those things whose presence in cities most of all produces evils both private and public" (Syse, 2010, p. 105-109).

Plato outlined a Just War Theory for the Kallipolis, detailing on what occasions it should go to war and how wars should be fought. But even if discussion of justice in war is allegorical, we can nonetheless say that the Republic contains a proto Just War Theory. This discussion is significant for no other reason than it was the first explicit discussion of the connection between justice and war. The Just City Just War Theory in the Republic, like the Just War Theory later developed along the framework developed by St. Augustine, can be divided into jus ad bellum and jus in bello. Plato did not intend for his thoughts on justice and war to be divided in such a way, as he approached the problem of war holistically. Aristotle plainly stated that war should always be fought for the sake of peace (Aristotle, 2013, Politics 1333a30). This peaceful telos of war, along with several other factors, leads us to see that Aristotle supported some of the central principles of what would become Western Just War Theory. However, several of the causes of war, such as war for the sake of enslavement and for resources, which are completely contrarian to Just War Theory, Aristotle argued were just by nature. But it is important to note that, regardless of the reasons that he gave, Aristotle wrote of war as something that needed to be justified ethically. Aristotle was content to define peace among Polis as simply the absence of war. Within a Polis peace is rather the establishment of an order that is in harmony with nature. Aristotle did not see war as something necessary for the proper cultivation of the human soul. While military training was necessary for the protection of the Polis, war and military training had no intrinsic value for a virtuous soul. Because he rejected the possibility of war or military affairs having value in and of themselves, Aristotle departed from the Greek creative warfare tradition (Aristotle, 2013, Politics 1333a30), p.80). Aristotle could only justify war by its outcomes: the protection or establishment of a just Polis. A just Polis, in turn, was meant to produce conditions that 
cultivate virtues in the human soul. Aristotle saw war as a natural process, an activity that is potentially in harmony with the cosmos. Classifying war as such a process made sense for Aristotle, as humans were a type of animal, the Politikon Zoon, who have specific purposes as natural beings (Aristotle, 2013, Politics 1253a2). Aristotle saw war as originating from humanity.

According to T. Hobbes, the idea of equality leads to an insecurity feeling. Human beings are inherently bad-evil and their natural situation is a war period. The main reason for people to go to war are competition, insecurity, honour and glory. Forcing is the greatest virtue and this can only be applied on society through the state. The law of nature refers to a war situation, however when the state emerges, human beings start to socialise and then find themselves at peace.

The company of the exiled royalists led Hobbes to produce Leviathan, which set forth his theory of civil government in relation to the political crisis resulting from war. Hobbes compared the State to a monster (Leviathan) composed of men, that state, each person would have a right, or license, to everything in the world. This, Hobbes argues, would lead to a "war of all against all". According to Hobbes, society is a population beneath a sovereign authority, to whom all individuals in that society cede some rights for the sake of protection. Any power exercised by this authority cannot be resisted because the protector's sovereign power derives from individuals' surrendering their own sovereign power for protection.

Locke, on the contrary to Hobbes, claim that in the state of nature, people mostly kept their promises and honored their obligations, it was mostly peaceful, good, and pleasant. Humans know what is right and wrong, and are capable of knowing what is lawful and unlawful well enough to resolve conflicts. We should live together in peace. Society creates order and grants the state legitimacy. State established to protect the natural situation. We give up our right to ourselves to exact retribution for crimes, in return for impartial justice backed by overwhelming force.

Rousseau claims that humans are born free, autonomous, and naturally virtuous, therefore a war situation revealed with the establishment of the state, is not a natural situation. In war, the power belongs to the state, not to the public. For Rousseau, social contract is needed, but it unavoidably creates inequality as well as peace and order. If man were more just and fair in his actions, social contract would be more beneficial to his life. In the natural state, we are naturally interested in our own welfare and are naturally compassionate about the suffering of others. However, civil society encourages us to think that we are superior to others and perverts our natural virtuous feelings, changing them into selfishness, pride, and delight in the misery of others.

Kant says the states have the right to go to war to defend their existence although war is the gravest injustice and should be avoided. Kant claims that any war can not be justified in answer to the just war theory. According to him, war, the basis of all vices and immoralities, therefore, governments are morally obligated to pursue peace. Each state will naturally fear other states, and this fear will often result in war. Kant called for a federation of states (vested with the authority to resolve conflicts among sovereign states. Although perpetual peace was a moral ideal for Kant, he did not regard it as an unattainable goal. Kant's prescriptions for peace are compiled in his influential Perpetual Peace (1795) in six codes.

1) No treaty of peace shall be held valid in which there is tacitly reserved matter for a future war.

2) No independent states, large or small, shall come under the dominion of another state by inheritance, exchange, purchase, or donation.

3) Standing armies shall in time be totally abolished.

4) National debts shall not be contracted with a view to the external friction of states.

5) No state shall by force interfere with the constitution o government of another state.

6) No state shall, during war, permit such acts of hostility which would make mutual confidence in the subsequent peace impossible: such are the employment of assassins, poisoners, breach of capitulation, and incitement to treason in the opposing state. He follows these with the conditions of perpetual peace at the national level. States should be republican, international law should be based on a federation of free states, and that universal hospitality should reign.

When we look at the 20th Century, we can see John Rawls' thoughts about war and peace. Rawls thinks that a well ordered democratic societies have no reason to go war with each other. In The Law of Peoples, Rawls addresses how it could have been that societies with a democratic history did indeed come to wage war against each other. A well-ordered people "does not have aggressive aims and it recognizes that it must gain its legitimate ends through diplomacy and trade and other ways of peace" (Rawls, The Law of Peoples, p. 64-66).

In wars, the uniformed forces made war and civil people was not affected a lot before the 21 st Century. The structure of war changed as technology advanced in the 21 st Century. The world is now a small town and the actions of human beings have been redefined through the development of information technologies. In meantime, travel and communication systems have become faster and this gives the weak characters the strength in society and this situation creates an atmosphere and environment to destroy enemies easily. Clausewitz says in his book "On War", the nature of war has changed its cover like a chameleon (Clausewitz, 1997, On War). In this context, we can see clearly that war's form is multidimensional in the $21 \mathrm{st}$ century, particularly terrorism, which disregards the rules of war and targets civilians directly in every area of normal life in a terrible way. Terrorism has systematically become a pressure instrument, in addition, they do not accept any laws of war. A terrorist represents both the weapon and war strategy with bombs on his/her body which shows us that in now, in the $21 \mathrm{st}$ century, war and war strategy has changed significantly. 


\section{REFERENCES}

[1] Kranz, Walter, 1984, Antik Felsefe, Sosyal Yayınlar, Istanbul

[2] Tzu, Sun, 2016, Savaş Sanat1, Anahtar Kitaplar Yayınevi, Istanbul.

[3] N. Baker and A.Stephens, 2009, Savaşı Anlamak, Phoenix yayınevi, Istanbul

[4] Kışlalı, Ahmet Taner, 2010, Siyasal Sistemler-Siyasal Çatışma ve Uzlaşma, Ankara, İmge Kitabevi, Ankara

[5] Syse, Henrik, (March 2010), THE PLATONIC ROOTS OF JUST WAR DOCTRINE: A READING OF PLATO'S REPUBLIC- Henrik Syse Diametros № 23 (March 2010): 104-123 Home > Diametros 23 (March 2010) >, An Online Journal of Philosophy- Diametros

[6] Plato, 1995, Devlet, Remzi kitapevi, Istanbul

[7] Aristotle, 2013, trans: Murat Temelli, Ark kitapları, Istanbul.

[8] J. Rawls, 2001, The Law of Peoples, Harward University Press, London 